Volume 1 Issue 2, September 2016: pp. 150-169. Copyright @ LamLaj. Faculty of Law, Lambung Mangkurat University, Banjarmasin, South Kalimantan, Indonesia. ISSN: 2502-3136 | e-ISSN: 2502-3128.

Open Access at: http: / /lamlaj.unlam.ac.id

\title{
Perlindungan Hukum Bagi Pihak Pembeli yang Beritikad Baik dalam Jual Beli Tanah
}

\author{
Hamdaliah \\ Program Magister Kenotariatan Fakultas Hukum Universitas Lambung Mangkurat. \\ Jl. Brigjend H. Hasan Basri Komplek Unlam Banjarmasin 70123 Indonesia \\ Telp/Fax: +62 5113307877 E-mail: hamdaliahadvokat@gmail.com.
}

Diterima: 25/7/2016; Revisi: 23/08/2016; Disetujui: 21/09/2016

\begin{abstract}
The purpose of this research is to study the legal protection of a good faith buyer in sale and purchase of land against bad faith seller and to study the judges' consideration in assessing the presence or absence of good faith in a sale and purchase agreement in case of dispute. The method of this research is normative legal research by studying the legal norms related to the object of research. Legal resources that have been using in this research were primary legal resources, secondary legal resources, and other resources which are not derived from the literature in order to support the analysis. Cases are included in order to cope with the problems well and precisely. The approach applied in this research is conceptual approach, by referring to the ideas and doctrines developed in the jurisprudence, especially with regard to analysis of the issues being dealt with. Type of the research is inventory of legislation. The collected rules shall become the reference in analyzing the issue as pointed out in the problem formulation of this research. The results of this show that: firstly, legal protection to a good faith buyer in the implementation of an agreement in this case the sale and purchase of land starting from pre-agreement stage up to post-agreement stage up to post-agreement stage must be enforced as stipulated in Article 1341, Article 1491 and Article 1942 of Civil Code. The content of the sale and purchase of land should also be rational or fair in accordance with the context of good faith as stipulated in Article 1338 paragraph (3) of the Civil Code, Secondly, the judges in their considerations have not yet got deep and consistent understanding on the meaning of good faith stated in Article 1338 paragraph (3) of the Civil Code. The standard applied by the judges in considering the existence of good faith in a land case or implementation of sale and purchase of land is objective standard, namely by referring to the attitude of the parties in performing the agreement. The assessment on the content of the sale and purchase agreement must be based on rationality and fairness.
\end{abstract}


Keywords: Legal Protection, buyers, Goodwill, Sale and Purchase of Land.

\begin{abstract}
Abstrak: Tujuan dari penelitian ini adalah untuk mempelajari perlindungan hukum dari pembeli itikad baik dalam jual beli tanah terhadap penjual itikad buruk dan mempelajari pertimbangan hakim dalam menilai ada tidaknya itikad baik dalam perjanjian jual beli dalam kasus sengketa. Metode penelitian ini adalah penelitian hukum normatif dengan mempelajari norma-norma hukum yang terkait dengan objek penelitian. Sumber hukum yang telah digunakan dalam penelitian ini adalah sumber utama hukum, sumber sekunder hukum, dan sumber daya lain yang tidak berasal dari literatur untuk mendukung analisis. Kasus yang termasuk dalam rangka untuk mengatasi masalah dengan baik dan tepat. Pendekatan yang digunakan dalam penelitian ini adalah pendekatan konseptual, dengan mengacu pada ide-ide dan doktrin yang dikembangkan dalam hukum, terutama berkaitan dengan analisis masalah yang ditangani, Jenis penelitian ini adalah persediaan undangundang. Aturan yang dikumpulkan akan menjadi acuan dalam menganalisis masalah seperti yang ditunjukkan dalam perumusan masalah penelitian ini. Hasil ini menunjukkan bahwa: pertama, perlindungan hukum kepada pembeli itikad baik dalam pelaksanaan perjanjian dalam hal ini jual beli tanah mulai dari tahap pra-perjanjian sampai dengan pascakesepakatan tahap hingga pasca-kesepakatan tahap keharusan ditegakkan sebagaimana diatur dalam Pasal 1341, Pasal 1491 dan Pasal 1942 KUH Perdata. Isi dari jual beli tanah juga harus rasional atau adil sesuai dengan konteks itikad baik sebagaimana diatur dalam Pasal 1338 ayat (3) KUHPerdata, Kedua, para hakim dalam pertimbangan mereka belum mendapat mendalam dan pemahaman yang konsisten tentang makna itikad baik tercantum dalam Pasal 1338 ayat (3) KUHPerdata.Standar yang diterapkan oleh hakim dalam mempertimbangkan adanya itikad baik dalam kasus tanah atau pelaksanaan jual beli tanah adalah standar obyektif, yaitu dengan mengacu pada sikap para pihak dalam melakukan perjanjian.Hasil pemeriksaan atas isi dari perjanjian jual beli harus didasarkan pada rasionalitas dan keadilan.
\end{abstract}

Kata-Kata kunci: Perlindungan Hukum, pembeli, Goodwill, Jual Beli Tanah.

\section{PENDAHULUAN}

Jual beli tidak dapat dipisahkan dari kehidupan rnasyarakat sehari-hari. Kejujuran atau itikad baik dalam jual beli merupakan faktor yang penting sehingga pernbeli yang beritikad baik akan rnendapat perlindungan hukum secara wajar, sedangkan yang tidak beritikad baik tidak perlu rnendapat perlindungan hukum.

Tanah rnerupakan peranan penting dalam kehidupan manusia baik sebagai surnber kehidupan rnaupun sebagai bentuk pernbangunan untuk digunakan bagi kemakmuran rakyat. Tanah rnerupakan salah satu kebutuhan pokok manusia juga dapat di gunakan sebagai kegiatan rnanusia, seperti tempat tertinggal dan pembangunan.

Maka manusia berlomba-lomba untuk rnenguasai dan rnemiliki bidang tanah yang diinginkan karena memiliki bidang ekonomis bagi segala aspek kehidupan manusia. Dengan ini untuk menciptakan kemakmuran dan kesejahteraan rakyat, maka permasalahan yang berkaitan dengan penggunaan pemilikan 
penguasahan dan jual beli tanah memerlukan perhatian yang khusus dalam peratuan perundang-undangan. Berbagai pengalaman historis telah membuktikan bahwa tanah sangat berhubungan erat dengan perilaku rnasyarakat bahkan tanah dapat menimbulkan masalah bila sendi-sendi perubahan tidak memiliki aturan sama sekali.

Betapa pentingnya tanah sebagai sumber daya hidup, maka tidak ada sekelompok masyarakatpun di dunia ini yang tidak memiliki norma-norma atau aturan-aturan tertentu dalam masalah pertahanan ini, penduduk bertambah, pemikiran manusia berkembang dan berkembang pulalah sistem, pola, struktur dan tata cara manusia menentukan sikapnya terhadap tanah.

Seiring dengan perubahan dan perkembangan pola pikir, pola hidup, dan kehidupan manusia maka dalam soal pertanahanpun terjadi perubahan, terutama dalam hal pemilikan dan penguasaannya dalam hal ini tentang kepastian hukum dan kepastian hak atas nama yang sedang atau yang akan dimilikinya.

Secara lahiriah, kehidupan manusia tidaklah dikendalikan tanpa hukum yang mengaturnya termasuk dalam suatu perjanjian jual beli. Tujuan perjanjian jual beli adalah memindahkan hak milik atau barang dari penjual kepada pembeli. Perjanjian jual beli selain bersifat konsensual juga bersifat obligatoir dalam arti meletakkan hak dan kewajiban bagi para pihak yaitu pihak penjual dan pihak pembeli. Seringkali dalam jual beli pembeli melakukan jual beli atas barang tanpa diketahui apakah penjual adalah pemilik barang atau bukan karena terhadap barang bergerak terdapat suatu suatu asas barang siapa yang menguasai kebendaan bergerak dianggap sebagai pemiliknya. Sehingga sering- kali pembeli yang beritikad baik membeli barang dirugikan jika di kemudian hari diketahui barang tersebut sebenarnya bukan milik penjual.

Ketentuan jual beli menurut hukum adat dan Undang-Undang Nomor 5 Tahun 1960 tentang Pokok-Pokok Agraria yang menyatakan bahwa proses jual beli bersifat tunai, terang, dan jelas yang berarti bahwa jual beli dan perpindahan hak milik sudah terjadi apabila antara penjual dan pembeli sudah mencapai kata sepakat mengenai harga dan barangnya sesuai dengan kesepakatan bersama. Salah satu permasalahan dalam hukum perdata terutama perjanjian jual beli adalah mengenai perlindungan terhadap pembeli beritikad baik. Itikad baik menurut Subekti adalah kejujuran. Orang yang beritikad baik menaruh kepercayaan sepenuhnya kepada pihak lawan, yang dianggapnya jujur dan tidak menyembunyikan sesuatu yang buruk yang kemudian hari akan menimbulkan kesulitan-kesulitan. Menurut Yurisprudensi Mahkamah Agung, jual beli yang dilakukan hanya berpura-pura (proforma) saja hanya mengikat terhadap pihak yang membuat perjanjian, dan tidak mengikat kepada pihak ketiga yang membeli dengan itikat baik. Itikad baik merupakan salah satu asas perjanjian yang diatur dalam Pasal 1338 ayat (3) KUHPerdata, bahwa perjanjian harus dilaksanakan dengan itikad baik. Pembeli yang telah bertindak dengan itikad baik harus dilindungi dan jual beli yang bersangkutan haruslah dianggap sah.

Contoh kasus pihak pembeli dirugikan, yaitu A membeli sebidang tanah beserta bangunan ruko di atasnya kepada B, yang terletak di Jalan Garuda, Kelurahan Komet, Kota Banjarbaru, dengan ukuran luas 95 $\mathrm{M}^{2}$ (sembilan puluh lima meter persegi), 
sebagaimana sertipikat hak miik No.02/95, jual beli ini dilakukan melalui Notaris/ PPAT di Banjarbaru. Setelah membeli dari B, A tidak langsung menempatinya dan tidak melakukan balik nama di BPN Kota Banjarbaru. Setelah beberapa bulan kemudian A meminta bantuan kepada C untuk proses balik nama sertipikat di BPN Banjarbaru, namun sampai satu tahun tidak selesai-selesai, temyata $\mathrm{C}$ tidak mengurusnya, atas dasar tersebut kemudian A melaporkan $\mathrm{C}$ ke polisi Pelaihari dan selanjutnya diproses di Pengadilan Negeri Pelaihari, dengan hasil putusannya menyatakan $\mathrm{C}$ bersalah melakukan penipuan dan/atau penggelapan.

Kemudian A mengurus sendiri ke BPN Banjarbaru untuk balik nama sertipikat, namun diketahui temyata sudah dibalik nama kepada D. Setelah ditelusuri temyata D membeli dari E, dan E telah membeli dari B, jual beli antara E dan B juga melalui Notaris/ PPAT di Banjarbaru. Atas kejadian tersebut A sebagai pembeli yang beritikad baik kemudian mengajukan gugatan perdata terhadap B, $\mathrm{E}$, dan $\mathrm{D}$, dengan dasar gugatan perbuatan melawan hukum (Pasal 1365 KUHPerdata) di Pengadilan Negeri Banjarbaru. ${ }^{1}$

\section{TEORI}

Jual beli adalah perjanjian konsensuil dapat ditemukan dalam rumusan Pasal 1458 Kitab Undang-Undang Hukum Perdata, yang berbunyi: jual beli itu telah dianggap terjadi antara kedua belah pihak, seketika setelah orang-orang ini mencapai kata sepakat tentang kebendaan dan harganya, meskipun kebendaan itu belum diserahkan maupun harganya belum dibayar.

1 Perkara perdata No.05 / Pdt.G / 2015 / PN.Bjb
Dari penjelasan tersebut, secara sederhana dapat dikatakan pada dasarnya setiap penerimaan yang diwujudkan dalam bentuk pernyataan penerimaan baik tertulis maupun lisan menunjukkan saat lahirnya perjanjian. Suatu perjanjian yang dibuat oleh seseorang dengan seseorang yang lain atau lebih akan menimbulkan suatu hubungan hukum yang dinamakan perikatan, jadi dapat disimpulkan perjanjian adalah sumber perikatan di samping sumber lainnya Wirjono Prodjodikoro, mengemukakan arti perjanjian sebagai suatu hubungan hukum mengenai harta benda antara dua pihak. dalam mana pihak berjanji atau dianggap berjanji untuk melakukan sesuatu hal atau tidak melakukan sesuatu hal, sedang pihak lain berhak menuntut pelaksanaan janji itu ${ }^{2}$

Menurut KUH Perdata, Buku Ketiga memuat asas-asas umum yang merupakan pedoman yang menjadi batas atau ramburambu dalam membuat perjanjian, yaitu:

a. Asas kebebasan berkontrak;

b. Asas konsensualisme,

c. Asas pacta sunt servanda;

d. Asas kepribadian (personalitas);

e. Asas itikad baik

Masing-masing asas perjanjian tersebut terdapat berbagai penjelasan dari para ahli hukum. Hal ini disebabkan KUHPerdata sendiri tidak memberikan penjelasannya Tentang kebebasan berkontrak, Kartini Muljadi dan Gunawan Widjaja, mengemukakan asas ini mendapatkan dasar eksistensinya dalam rumusan Pasal 13-20 angka 4 KUHPerdata sepanjang tidak bertentangan dengan Pasal 1337 KUHPerdata. Artinya, semua perjanjian dap-at dibuat dan diselenggarakan oleh setiap

2 R. Wiijono Prodjodikoro,1983,Azas-Azas Hukum Perdata, Bandung, Sumur, hlm.9 
orang asal tidak melanggar undang-undang, kesusilaan dan ketertiban umum. ${ }^{3}$

Salim HS, mengemukakan asas kebebasan berkontrak dapat dianalisis dari ketentuan Pasal 1338 ayat (1) KUHPerdata. Asas ini memberikan kebebasan kepada para pihak untuk: ${ }^{4}$

a. Membuat atau tidak membuat perjanjian.

b. Mengadakan perjanjian dengan siapapun.

c. Menentukan isi perjanjian, pelaksanaan, danpersyaratannya.

d. Menentukan bentuknya perjanjian, yaitu tertulis atau lisan.

Handri Raharjo, mengemukakan asas kebebasan berkontrak bermakna setiap orang bebas membuat perjanjian dengan siapapun, apapun isinya, apapun bentuknya sejauh tidak melanggar undang-undang, ketertiban umum, dan kesusilaan (Pasal 1337 dan 1338 KUH Perdata). ${ }^{5}$ Dalam perkembangannya asas ini tidak lagi bersifat mutlak tetapi relatif (kebebasan berkontrak yang bertanggung jawab). Asas inilah yang menyebabkan hukum perjanjian bersistem terbuka.

Tentang asas konsensualisme, menurut Kartini Muljadi dan Gunawan Widjaja, ${ }^{6}$ dapat ditemui dalam rumusan Pasal 1320 angka 1 KUHPerdata, pada dasarnya semua perjanjian yang dibuat secara lisan antara dua atau lebih orang telah mengikat, dan

3 Kartini Muljadi \& Gunawan Widjaja, 2004, Perikatan Yang Lahir dari Perjanjian, Jakarta, PT. Raja Grafindo Persada, hlm. 45-46.

4 Salim HS, 2003, Hukum Kontrak Teorie Teknik Penyusunan Kontrak, Jakarta, Sinar Graflka, hlm.9.

5 Handri Raharjo, 2009, Hukum Perjanjian di Indonesia, Yogyakarta, Pustaka Yustisia, hlm. 43-44

6 Kartini Muljadi \& Gunawan Widjaja, Op.cit, hlm.34-35. karenanya telah melahirkan kewajiban bagi salah satu atau lebih pihak dalam perjanjian tersebut. Ini berlaku sebagai perikatan bagi para pihak yang berjanji tidak memerlukan formalitas, walaupun demikian untuk menjaga kepentingan pihak debitor (atau yang berkewajiban untuk memenuhi prestasi) diadakanlah bentuk-bentuk formalitas atau dipersyaratkan adanya suatu tindakan nyata. ${ }^{7}$

Mariam Darus Badrulzaman, mengemukakan teori saat terjadinya kesepakatan perjanjian: ${ }^{8}$

a. Teori kehendak (wilstheorie), yang mengajarkan kesepakatan terjadi pada saat kehendak pihak penerima dinyatakan, misalnya dengan menulis surat.

b. Teori pengiriman (verzendtheorie), yang mengajarkan kesepakatan terjadi pada saat kehendak dinyatakan dikirim oleh pihak yang menerima tawaran.

c. Teori pengetahuan (vernemingstheorie), yang mengajarkan pihak yang menawarkan seharusnya sudah mengetahui bahwa tawarannya diterima.

d. Teori kepercayaan (vertrouwenstheorie), yang mengajarkan kesepakatan terjadi pada saat pernyataan kehendak dianggap layak diterima oleh pihak yang menawarkan.

Henry P. Panggabean, mengutip pernyataan Subekti, bahwa hukum perjanjian dari KUHPerdata mencakup asas konsensualisme yang melahirkan perjanjian cukup dengan sepakat saja dan perjanjian itu (dan dengan"perikatan" yang ditimbulkan Karenanya) sudah dilahirkan pada saat atau

\footnotetext{
$7 \quad$ Ibid, hlm.40

8 Mariam Darius Badrulzaman, 2001, Kompilasi Hukum Perikatan, Bandung, PT. Citra Aditya Bakti, hlm.94
} 
detik tercapainya konsensus sebagaimana di atas pada detik tersebut perjanjian sudah jadi dan mengikat bukannya pada detikdetik yang lain yang terkemudian atau yang sebelumnya. ${ }^{9}$ Asas konsesualisme merupakan tuntutan kepastian hukum bahwa orang yang hidup dalam masyarakat yang teratur harus dipegang perkataannya atau ucapannya, untuk mengukur atau menilai apakah telah tercapai suatu consensus harus dilihat pada pernyataanpernyataan yang telah dilakukan oleh kedua belah pihak, pada satu pihak ada yang menawarkan (offerte) dan dilain pihak yang menerima penawaran itu. ${ }^{10}$ Dan apabila timbul perselisihan tentang apakah telah dilahirkan suatu perjanjian atau tidak maka hakim atau pengadilan yang akan menetapkannya. ${ }^{11}$

Tentang asas pacta sun servanda, oleh Kartini Muljadi dan Gunawan Widjaja ${ }^{12}$ diterjemahkan menjadi perjanjian berlaku sebagai undang-undang. Oleh Kartini Muljadi dan Gunawan Widjaja lebih jauh mengemukakan asas yang diatur dalam Pasal 1338 ayat (1) KUHPerdata merupakan konsekuensi logis dari ketentuan Pasal 1233 KUHPerdata, yang menyatakan bahwa setiap perikatan dapat lahir dari undang-undang maupun karena perjanjian. ${ }^{13}$ Jadi perjanjian adalah sumber dari perikatan. Sebagai perikatan yang dibuat dengan sengaja, atas kehendak para pihak secara sukarela, maka segala sesuatu yang telah disepakati, disetujui

9 Henry P. Panggabean, 2011, Penyalahgunaan Keadaan (Misbruik Van Omstandigheden sebagai Alasan (Baru) untuk Pembatalan Perjanjian (Berbagai Perkembangan Hukum di Belanda), Yogyakarta, Liberty, hlm.15

10 Ibid

11 Ibid, hlm. 16

12 Kartini Muljadi \& Gunawan Widjaja, Op. cit, hlm.59

13 Ibid oleh para pihak harus dilaksanakan oleh para pihak sebagaimana telah dikehendaki oleh mereka. ${ }^{14}$

Salim HS, mengemukakan asas pacta sunt servanda atau disebut juga dengan asas kepastian hukum. Asas ini berhubungan dengan akibat perjanjian. Asas pacta sunt servanda adalah asas bahwa hakim atau pihak ketiga harus menghormati substansi kontrak yang dibuat oleh para pihak sebagaimana layaknya sebuah undang-undang. ${ }^{15}$ Mereka tidak boleh melakukan intervensi terhadap substansi kontrak yang dibuat oleh para pihak. Asas pacta sunt servanda dapat disimpulkan dalam Pasal 1338 ayat (1) KUHPerdata, yang berbunyi: "Perjanjian yang dibuat secara sah berlaku sebagai undang-undang". ${ }^{16}$

Tentang asas itikad baik (Goede Trouw), Purwahid Patrik menunjuk Pasal 1338 ayat (3) dan Pasal 1339 KUH Perdata. Dengan dimasukkannya itikad baik dalam pelaksanaan perjanjian berarti tidak lain harus menafsirkan perjanjian itu berdasarkan keadilan dan kepatuhan. Menafsirkan suatu perjanjian adalah menetapkan akibat-akibat yang terjadi. ${ }^{17}$

Tentang asas kepribadian (Personalitas), menurut Mariam Darius Badrulzaman, pada asasnya suatu perjanjian berlaku bagi pihak yang mengadakan perjanjian itu sendiri. Asas ini merupakan asas pribadi (Pasal 1315 jo 1340 KUHPerdata). Para pihak tidak dapat mengadakan perjanjian yang mengikat pihak

14 Ibid

15 Salim HS, Op.cit, hlm. 10-11

16 Kartini Muljadi \& Gunawan Widjaja, Op.cit, hlm.69

17 Purwahid Patrik, 1994, Dasar-dasar Hukum Perikatan (Perikatan Yang Lahir Dari Perjanjian dan dari Undang-undang), Bandung, CV. Mandar Maju, hlm.67. 
ketiga, kecuali dalam apa yang disebut janji guna pihak ketiga (beding ten behoove van derden) Pasal 1317 KUHPerdata. ${ }^{18}$

Kartini Muljadi dan Gunawan Widjaja, ${ }^{19}$ lebih jauh menjelaskan tentang asas personalia yang menurutnya dapat ditemukan dalam ketentuan Pasal 1315 KUHPerdata, yang berbunyi: "pada umumnya tak seorangpun dapat mengikatkan diri atas nama sendiri atau meminta ditetapkannya suatu janji selain untuk dirinya sendiri. Dari rumusan tersebut dapat diketahui bahwa pada dasarnya suatu perjanjian yang dibuat oleh seseorang dalam kapasitasnya sebagai individu, subyek hukum pribadi, hanya akan berlaku dan mengikat untuk dirinya sendiri.

Meskipun secara sederhana dikatakan bahwa ketentuan Pasal 1315 KUHPerdata, menunjuk pada kewenangan bertindak dari seorang yang membuat atau mengadakan perjanjian. Secara spesifik ketentuan Pasal 1315 KUHPerdata ini menunjuk pada kewenangan bertindak untuk dan atas namanya sendiri. Dengan kapasitas kewenangan tersebut, sebagai seorang yang cakap bertindak dalam hukum, maka setiap tindakan, perbuatan yang dilakukan oleh orang perorangan, sebagai subyek hukum pribadi yang mandiri, akan mengikat diri pribadi tersebut, dan dalam lapangan perikatan, mengikat seluruh harta kekayaan yang dimiliki olehnya secara pribadi. Pasal 11-31 KUHPerdata berlaku bagi dirinya pribadi, yang menentukan: "Segala kebendaan milik debitor, baik yang bergerak maupun tidak bergerak, baik yang sudah ada maupun yang baru akan ada di kemudian hari,

\footnotetext{
18 Mariam Darus Badrulzaman, Op.cit, hlm.94

19 Kartini Muljadi \& Gunawan Widjaja, Op.cit, hlm.14-15.
}

menjadi tanggungan untuk segala perikatannya perseorangan". ${ }^{20}$

Kata "jual beli" menunjukkan bahwa salah satu pihak dinamakan penjual, sedangkan dari pihak lain dinamakan pembeli. Istilah yang mencakup dua perbuatan yang bertimbal balik itu adalah besesuai dengan istilah Belanda "koop en verkoop" yang juga mengandung pengertian bahwa pihak yang satu "verkoopt" (menjual), sedangkan yang lainnya menjual “koop" (membeli). Dalam bahasa Inggris jual beli disebut dengan hanya "sale" saja yang berarti "penjualan" (hanya dilihat dari sudut si penjual), begitu pula dalam bahasa Prancis disebut hanya dengan "vente" yang berarti "penjualan", sedangkan dalam bahasa Jerman dipakainya perkataan "kauf" yang berarti "pembeli".

Pada saat terjadinya jual beli maka harus terpenuhi unsur pokok (essentialia), dimana perjanjian jual beli adalah barang dan harga berdasarkan asas konsensualisme. Perjanjian jual beli itu sudah dilahirkan pada detik tercapainya sepakat mengenai barang dan harga. Begitu kedua belah pihak sudah setuju tentang barang dan harga, maka lahirlah perjanjian jual beli yang sah. Sifat konsensuil dari jual beli tersebut ditegaskan dalam Pasal 1458 KUHPerdata, yang berbunyi: "Jual beli sudah dianggap terjadi antara kedua belah pihak seketika setelah mereka mencapai sepakat tentang barang dan harga, meskipun barang itu belum diserahkan dan harga belum dibayar. Kata sepakat dapat diberikan secara tegas maupun diam-diam. Secara tegas dapat dilakukan secara tertulis, lisan maupun suatu benda tertentu. Secara tertulis seperi akta oetentik maupun akta di bawah tangan.
20 Ibid 
Terjadinya kata sepakat terdapat empat teori, yaitu: ${ }^{21}$

1. Teori Ucapan (Uitings Theorie), ini berpijak kepada salah satu prinsip hukum bahwa suatu kehendak baru memiliki arti apabila kehendak itu telah dinyatakan. Jadi menurut teori ini kata sepakat terjadi pada saat pihak yang menerima penawaran telah menulis surat jawaban yang menyatakan dia menerima surat pernyataan. Kelemahan dari teori ini adalah tidak adanya kepastian hukum karena pihak yang memberikan tawaran tidak tahu persis kapan pihak yang menerima tawaran tersebut memberikan jawaban.

2. Teori Pengiriman (Verzendings Theorie), menurut teori ini kesepakatan terjadi apabila pihak yang menerima penawaran telah mengirimkan jawaban atas penawaran yang diajukan kepadanya. Kelemahan teori ini adalah kadang terjadi perjanjian yang telah lahir diluar pengetahuan orang yang melakukan penawaran tersebut, selain itu akan muncul pe-rsoalan jika penerimamenundanunda untuk mengirimkan jawaban.

3. Teori Penerimaan (Ontvangs Theorie), terjadi pada saat pihak yang menawarkan menerima langsung surat jawaban dari pihak yang menerima tawaran.

4. Teori Pengetahuan (Vernemings Theorie) bahwa kesepakatan terjadi pada saat yang melakukan penawaran mengetahui bahwa penawaranya telah oleh pihak yang menerima penerimaan tersebut. Kelemahan teori ini antara lain memung-

21 Ramli, Ahmad, M, 2006, Cyber Law dan Haki Dalam Sistem Hukum Indonesia, Bandung, Refika Aditama, hlm.21 kinkan terlambat lahimya perjanjian karena menunda-nunda untuk membuka surat penawaran dan sukar untuk mengetahui secara pasti kapan penerima tawaran mengetahui isi surat penawaran.

Kesepakatan dimaksudkan bahwa para pihak-pihak yang bersangkutan tercapai sesuaatu persesuaian kehendak, artinya apa yang dikehendaki oleh yang satu sama dengan yang dikehendaki oleh satu lainnya, tetapi itu belum dapat dikatakan sepakat sebelum kedua belah pihak mengucapkan kata-kata "setuju", "oke" dan "accorcd"22 dan lain sebagainya atau dengan bersama-sama menaruh tandatangan di bawah pernyataanpernyataan tertulis sebagai tanda kedua belah pihak su-dah setuju isi pernyataan tersebut. Apa yang dikehendaki dalam hal ini misalnya adalah yang satu ingin melepaskan haknya atas suatu barang asal diberi sejumlah uang tertentu sebanyak gantinya, sedangkan yang lainnya ingin memperoleh atau memiliki hak milik atas batang tersebut, dan bersedia memberikan sejumlah uang sebagai gantinya kepada pemilik barang. ${ }^{23}$

\section{METODE}

Jenis penelitian yang digunakan oleh peneliti sesuai dengan latar belakang perumusan masalah dan manfaat yang diharapkan, adalah penelitian hukum normative dengan meneliti norma-norma hukum yang berkaitan dengan obyek penelitian. Bahan hukum yang digunakan adalah bahan hukum primer, bahan hukum sekunder, bahan hukum tidak yang berasal dari peneletian kepustakaan untuk mendukung analisis maka diajukan kasus agar 
bisa menjawab permasalahan dengan baik dan tajam.

Dalam penelitian ini peneliti menggunakan tipe penelitian yang berkaitan dengan permasalahan yang dianalisis, yaitu melalui pendekatan undang-undang (statute approach), dalam hal ini peneliti akan menelaah KUHPerdata, Buku Ketiga, tentang Perikatan, khususnya perikatan yang lahir dari perjanjian dan asas-asas dalam suatu perjanjian, lebih khusus penelitian akan meneliti asas hukum itikad baik dalam hukum perjanjian tersebut. Sebagaimana dikemukakan oleh Peter Mahmud Marzuki, ${ }^{24}$ arti pentingnya asas-asas hukum, adalah bagi pembentukan hukum memberikan landasan secara garis besar mengenai ketentuanketentuan yang perlu dituangkan dalam aturan-aturan hukum, bagi penerapan hukum sangat membantu digunakannya penafsiran dan penemuan hukum maupun analogi, bagi pengembangan ilmu hukum mempunyai kegunaan untuk menunjukkan berbagai aturan hukum yang pada tingkat lebih tinggi sebenarnya merupakan satu kesatuan. ${ }^{25}$ Selain itu peneliti menggunakan pendekatan konseptual (conceptual approach), yang beranjak dari pandangan dan doktrin yang berkembang dalam ilmu hukum, khususnya yang berkaitan dengan analisis terhadap permasalahan yang diangkat.

Sifat penelitian ini deskriptif, yaitu menggambarkan dan menjelaskan hasil analisis terhadap obyek penelitian "Perlindungan Hukum Bagi Pihak Pembeli Yang Beritikad Baik Dalam Jual Beli Tanah”.

24 Peter Mahmud Marzuki, 2005, Penelitian Hukum, Jakarta, Prenada Media, hlm.79

25 Ibid
Dalam pengolahan analisis permasalahan, bahan hukum primer, bahan hukum sekunder, dan bahan hukum tersier dihimpun dan diolah berdasarkan langkah-langkah normatif, yaitu mengadakan inventarisasi, kemudian dianalisis secara kualitatif untuk memberikan jawaban atas permasalahan dalam penelitian ini.

\section{ANALISIS DAN PEMBAHASAN}

\section{A. Jual Beli Menurut Hukum Adat, Hukum Perdata (KUHPerdata), dan Hukum Agraria.}

Berbicara jual beli tidak terlepas dari konsep perjanjian secara mendasar sebagaimana termuat dalam Pasal 1313 KUHPerdata yang menegaskan bahwa perjanjian adalah suatu perbuatan dengan mana satu orang atau lebih mengikatkan dirinya terhadap satu orang lain atau lebih. Ketentuan yang mengatur tentang perjanjian terdapat dalam Buku III KUHPerdata yang memiliki sifat terbuka artinya ketentuan-ketentuannya dapat dikesampingkan sehingga berfungsi mengatur saja. ${ }^{26}$ Sifat terbuka dari KUHPerdata ini tercermin dalam Pasal 1338 ayat (1) KUHPerdata yang mengandung asas kebebasan berkontrak maksudnya setiap orang bebas untuk menentukan bentuk macam dan isi perjanjian asalkan tidak bertentangan dengan peraturan perundang-undangan yang berlaku, kesusilaan, dan ketertiban umum, serta selalu memperhatikan syarat sahnya perjanjian sebagaimana termuat dalam Pasal 1320 KUHPerdata yang mengatakan bahwa syarat sahnya sebuah perjanjian adalah sebagai berikut: ${ }^{27}$

1. Kesepakatan para pihak dalam perjanjian.

\footnotetext{
26 Gunawan Widjaja dan Kartini Muljadi, Op.cit, hlm.359

27 Ibid
} 
2. Kecakapan para pihak dalam perjanjian

3. Suatu hal tertentu

4. Suatu sebab yang halal.

Kesepakatan berarti adanya persesuaian kehendak para pihak yang membuat perjanjian sehingga dalam melakukan suatu perjanjian tidak boleh ada paksaan, kekhilafan dan penipuan (dwang, dwaling, bedrog). Kecakapan hukum sebagai salah satu syarat sahnya suatu perjanjian, maksudnya para pihak yang melakukan perjanjian haruslah telah dewasa yaitu telah berusia 18 tahun atau telah menikah, sehat mentalnya serta diperkenankan oleh undang undang. Apabila orang yang belum dewasa hendak melakukan sebuah perjanjian, maka dapat diwakili oleh orang tua atau walinya sedangkan orang yang cacat mental dapat diwakili oleh pengampu atau curatonya. ${ }^{28}$ Suatu hal tertentu berhubungan dengan objek perjanjian, maksudnya objek perjanjian itu harus jelas, dapat ditentukan dan diperhitungkan jenis dan jumlahnya, diperkenankan oleh undang-undang serta mungkin untuk dilakukan para pihak. Suatu sebab yang halal, berarti perjanjian termaksud harus dilakukan berdasarkan itikad baik. Berdasarkan Pasal 1335 KUHPerdata, suatu perjanjian tanpa sebab tidak mempunyai kekuatan. Sebab dalam hal ini adalah tujuan sebuah perjanjian. ${ }^{29}$

Kesepakatan para pihak dan kecakapan para pihak merupakan syarat sahnya perjanjian yang bersifat subyektif. Apabila tidak terpenuhi, maka perjanjian dapat dibatalkan artinya selama dan sepanjang para pihak tidak membatalkan perjanjian, maka perjanjian masih tetap berlaku. Sedangkan suatu hal tertentu dan suatu sebab yang halal

28 Ibid, hlm.360

29 Ibid merupakan syarat sahnya perjanjian yang bersifat objektif. Apabila tidak terpenuhi, maka perjanjian batal demi hukum artinya sejak semula dianggap tidak pemah ada perjanjian. Pada kenyataannya banyak perjanjian yang tidak memenuhi syarat sahnya perjanjian secara keseluruhan, misalnya unsur kesepakatan sebagai persesuian kehendak dari para pihak yang membuat perjanjian yang sekarang saat ini telah mengalami pergeseran dalam pelaksanaannya. ${ }^{30}$

Jual beli di Indonesia secara umum masih bersifat pluralisme karena jual beli dalam masyarakat masih berdasarkan pada tiga hukum yang berbeda sesuai dengan kesepakatan dari masing-masing pihak, tiga hukum yang berlaku dalam jual beli yaitu: ${ }^{31}$

1. Ketentuan Hukum Adat mengenai jual beli benda bergerak dan benda tidak begerak termasuk tanah.

2. Ketentuan Kitab Undang-Undang Hukum Perdata (KUH-Perdata), mengenai jual beli benda bergerak dan benda tidak bergerak sepanjang bukan mengenai tanah.

3. Ketentuan Undang-Undang No.5 Tahun 1960 tentang Pokok-Pokok Agraria (UUPA) mengenai benda tidak bergerak khususnya tanah.

Jual beli tanah menurut hukum adat terdapat satu perbuatan hukum, yaitu hak atas tanah berpindah dari penjual kepada pembeli pada saat dibayarnya harga tanah secara tunai (contant) oleh pembeli kepada penjual.

Jual beli tanah menurut hukum adat bukan merupakan perjanjian sebagaimana yang ditegaskan dalam Pasal 1457 KUHPerdata,
30 Ibid
31 Ibid, hlm. 361 
melainkan suatu perbuatan hukum yang dimaksudkan untuk memindahkan hak atas tanah dari pemegang hak (penjual) kepada pihak lain (pembeli) dengan pembayaran sejumlah uang secara tunai (contant) dan dilakukan di hadapan kepala desa/kepala adat setempat (bersifat terang).

\section{B. Perjanjian Jual Beli dan Pihak Yang Beritikad Baik.}

Suatu perikatan adalah suatu perhubungan hukum antara dua orang atau pihak, berdasarkan mana pihak yang satu berhak menuntut sesuatu hal dari pihak yang lain dan pihak lain berkewajiban untuk memenuhi tuntutan. ${ }^{32}$

Hubungan hukum yang menerbitkan perikatan itu, bersumber pada apa yang disebut dengan perjanjian atau sumber lainnya, yaitu undangundang. Dengan demikian hubungan antara perikatan dengan perjanjian adalah bahwa perjanjian itu menerbitkan perikatan. Perjanjian adalah sumber terpenting yang melahirkan perikatan, karena perjanjian merupakan perbuatan hukum yang dilakukan oleh dua pihak, sedangkan perikatan lahir dari undang-undang dibuat tanpa kehendak dari para pihak yang bersangkutan. Jadi perikatan adalah suatu pengertian yang abstrak, sedangkan perjanjian adalah suatu hal yang konkrit atau merupakan suatu peristiwa. ${ }^{33}$

Jual beli yang dimaksudkan disini adalah jual beli hak atas tanah. Dalam praktik disebut jual beli tanah. Secara yuridis, yang diperjualbelikan adalah hak atas tanah bukan tanahnya.

Dalam perjanjian dikenal asas itikad baik, yang artinya setiap orang yang membuat perjanjian harus dilakukan dengan itikad baik.

32 Subekti.R, 1978, Hukum Perjanjian, Cetakan VII, Bandung, Intermasa, hlm.1

33 Ibid. hlm. 2
Dinyatakan oleh Muhammaad Faiz bahwa: ${ }^{34}$ ltikad baik adalah suatu pengertian yang abstrak dan sulit untuk dirumuskan, sehingga orang lebih banyak merumuskannya melalui peristiwa-peristiwa di pengadilan. ltikad baik dalam pelaksanaan perjanjian berkaitan dengan masalah kepatutan dan kepantasan. Kesulitan dalam perumusan mengenai definisi itikad baik tersebut tidak menjadikan itikad baik sebagi suatu istilah yang asing, melainkan hanya terlihat pada perbedaan definisi yang diberikan oleh beberapa ahli, termasuk dalam Black's Law Dictionary.

ltikad baik menurut M.L Wry adalah: "Perbuatan tanpa tipu daya, tanpa tipu muslihat, tanpa cilat-cilat, akal-akal, tanpa mengganggu pihak lain, tidak dengan melihat kepentingan sendiri saja, tetapi juga dengan melihat kepentingan orang lain". 35

Dalam Black's Law Dictiona-ry Itikad baik didefenisikan sebagai: "In or with good faith, honestly, openly and sincerely, without deceit or fraudtruly, actually, without simulation or pretense." 36

Selanjutnya Sutan Remy Sjahdeini secara umum menggambarkan itikad baik sebagai berikut:" "ltikad baik adalah niat dari pihak yang satu dalam suatu perjanjian untuk tidak merugikan mitra janjinya maupun tidak

34 Muhammad, Faiz, Kemungkinan diajukan Perkara dengan Klausula Arbitrase ke Muka Pengadilan, www.panmuhammadfaiz.co, diunduh 12 Nopember 2015, hlm.2

35 Khoirul, Hukum Kontrak, Slide 1.Ppt. Http//:Sunan-ampel.ac.id, diunduh tanggal 20 Desember 2016

36 Ibid

37 Sjahdeni Sutan Remy. 1993, Kebebasan Berkontrak dan Perlindungan Seimbang bagi Para Pihak dalam Perjanjian Kredit di Indonesia. Jakarta, Institut Bankir Indonesia, hlm.94 
merugikan kepentingan umum". Mengenai pembagian asas itikad baik, diuraikan oleh Muliadi Nur, sebagai berikut: ${ }^{38}$

Asas itikad baik ini dapat di-bedakan atas itikad baik yang subyektif dan itikad baik yang obyektif. Itikad baik dalam pengertian yang subyektif dapat diartikan sebagai kejujuran seseorang atas dalam melakukan suatu perbuatan hukum, yaitu apa yang terletak pada sikap batin seseorang pada saat diadakan suatu perbuatan hukum. Sedang itikad baik dalam pengertian yang obyektif dimaksudkan adalah pelaksanaan suatu perjanjian yang harus didasarkan pada norma kepatutan atau apa yang dirasakan patut dalam suatu masyarakat.

Itikad baik secara subyektif menunjuk pada sikap batin atau unsur yang ada dalam diri pembuat, sedangkan itikad baik dalam arti obyektif lebih pada hal-hal diluar diri pelaku. Mengenai pengertian itikad baik secara subyektif dan obyektif, dinyatakan oleh Muhamad Faiz bahwa:"39 "ltikad baik subyektif, yaitu apakah yang bersangkutan sendiri menyadari bahwa tindakannya bertentangan dengan itikad baik, sedangkan itikad baik obyektif adalah kalau pendapat umum menganggap tindakan yang demikian adalah bertentangan dengan itikad baik". ${ }^{40}$

Itikad baik dalam sebuah penjanjian harus ada sejak perjanjian baru akan disepakati, artinya itikad baik ada pada saat negosiasi prakesepakatan perjanjian, dinyatakan oleh Ridwan Khairandy bahwa: ${ }^{41}$ Itikad baik sudah

38 Nur, Muliadi. Asas Kebebasan Berkontrak dalam Kaitannya dengan Perjanjian Baku (Standard Contract). www.pojokhukum.com, diunduh tanggal 15 Desember 2015.

39 Muhammad, Faiz, Op. cit, hlm.5

40 Ibid

41 Ridwan, Khairandy, Op.cit, hlm. 190 harus ada sejak fase prakontrak dimana para pihak mulai melakukan negosiasi hingga mencapai kesepakatan danfase pelaksanaan kontrak. Jenis standar subjektif itikad baik yaitu membebaskan konotasi moralistik dari motif terlarang atau ketidakjujuran. Itu membedakan pihak-pihak yang sengaja melakukan diskresi bagi alasan yang diperbolehkan kontrak, dan pihak-pihak yang bertindak bagi alasan yang tidak diperbolehkan kontrak. Itikad baik dapat terjadi jika suatu pihak yang melakukan diskresi memiliki suatu exclude reason, seperti suatu pergerakan harga yang menguntungkan, dan dimotivasi oleh alasan untuk tidak memberi keuntungan kontrak. Ini terjadi standar subjektif yang difokuskan pada maksud at-au kehendak (intention), dengan tidak mensyaratkan motif yang salah terla-rang atau ketidakjujuran. ${ }^{42}$

\section{Perlindungan Hukum Bagi Pembeli Yang Beritikad Baik Dari Penjual Yang Tidak Beritikad Baik.}

Dalam jual beli, khususnya jual beli tanah, tentunya ada hal-hal yang harus diperhatikan, seperti status hukum tanah tersebut, apakah dalam sengketa atau sedang dalam jaminan atau tidak, hal itu biasanya tercantum dalam surat pernyataan tidak dalam sengketa, yang ditandatangani oleh penjual dan ketahui oleh pejabat daerah dimana obyek jual beli tersebut berada. Tidak dipungkiri perbuatan hukum seperti jual beli sering dilakukan dalam kehidupan masyarakat sehari-hari.

Pada hakikatmya perjanjian jual beli itu bertujuan untuk memindahkan suatu hak milik atas suatu barang yang diperjualbelikan karena dalam jual beli pihak penjual wajib menyerahkan barang yang dijualnya itu kepada pembeli, sedangkan pihak pembeli

$42 \quad$ Ibid, hlm.205 
mempunyai kewajiban untuk membayar harga barang tersebut kepada pihak penjual.

Perlindungan hukum bagi pembeli yang beritikad baik juga harus melakukan pendaftaran tanah ke Kantor Pertanahan sebagaimana diatur dalam Pasal 1 angka (1) Peraturan Pemerintah No.24 Tahun 1997 tentang Pendaftaran Tanah.

Perlindungan hukum bagi para pihak dalam perjanjian apabila perjanjian pengikatan jual beli tersebut dibuat dihadapan atau oleh pejabat yang berwenang dalam hal ini notaris atau pejabat pembuat akta tanah, dengan dibuatnya perjanjian tersebut dalam bentuk akta notaris atau akta pejabat pembuat akta tanah, maka dengan sendirinya akta perjanjian tersebut menjadi akta yang notariil sehingga kekuatan perlindungannya sesuai dengan perlindungan terhadap akta otentik dan kembali kepada ketentuan yang terdapat dalam Pasal 1338 KUHPerdata yang berlaku sebagai undang-undang bagi para pihak. ${ }^{43}$

Perlindungan hukum menurut Satjipto Raharjo, adalah: "memberikan pengayoman terhadap Hak Asasi Manusia (HAM) yang dirugikan orang lain dan perlindungan itu diberikan kepada masyarakat agar dapat menikmati semua hak-hak yang diberikan oleh hukum". ${ }^{44}$

Perlindungan hukum menurut Maria Theresia Geme, adalah: "Berkaitan dengan tindakan negara untuk melakukan sesuatu dengan (memberlakukan hukum negara secara eksklusif) dengan tujuan untuk memberikan jaminan kepastian hak-hak seseorang atau

43 Sarjipto Rahardjo, 2000, Ilmu Hukum, Bandung, PT. Citra Aditya Bakti, hlm.54

44 Ibid kelompok orang". ${ }^{45}$ Definisi perlindungan tersebut kurang lengkap karena bentuk perlindungan dan subyek yang dilindungi berbeda antara satu dengan lainnya, oleh karena perlindungan itu adalah: "upaya atau bentuk pelayanan yang diberikan oleh hukum kepada subjek hukum serta hal-hal yang menjadi objek yang dilindungi" 46

Pengertian perlindungan hukum lainnya adalah suatu perlindungan yang diberikan terhadap subyek hukum dalam bentuk perangkat hukum yang bersifat preventif maupun bersifat repsesif, baik yang tertulis maupun tidak tertulis. Dengan kata lain perlindungan hukum sebagai gambaran dari fungsi hukum, yaitu konsep dimana hukum dapat memberikan suatu keadilan, ketertiban, kepastian, kemanfaatan dan kedamaian. ${ }^{47}$ Suatu pembentukan peraturan perundangundangan merupakan wujud perlindungan secara preventif, karena mencegah terjadinya sengketa.

Perlindungan preventif yang terkait dengan jual beli tanah, bagi pembeli yang beritikad baik terhadap penjual yang tidak beritikad baik, dengan memberikan saksi dalam setiap perjanjian, hal ini setidaknya dapat meminimalisir terjadinya resiko. Keterangan saksi nantinya dapat dijadikan alat bukti dalam persidangan, hal tersebut

45 Maria Theresia Geme, 2012, "Perlindungan Hukum terhadap Masyarakat Hukum Adat dalam Pengelolaan Cagar Alam Wattu Ata Kabupaten Ngada, Provinsi Nusa Tenggara Timur, Malang, Disertasi Program Dokter Ilmu Hukum Fakutas Hukum Universitas Brawijaya hlm.99.

46 Salim HS \& Erlies Septiana Nurbaini, 2013, Penerapan Teori Hukum Pada Penelitian Tesis Dan Disertasi, Jakarta, PT.RajaGrafindo Persada, hlm. 262.

47 Salman,http://prasxo. wordpress.com/20 11102/17I/definisi-perlindungan-hukum/diakses pada tanggal 18 Desember 2015. 
diatur dalam buku ke empat KUHPerdata, yakni: "Kesaksian adalah kepastian hukum yang dibeikan kepada Hakim di persidangan tentang peristiwa yang disengketakan dengan jalan pemberitahuan secara lisan dan pribadi oleh orang yang bukan salah satu pihak dalam perkara, yang dipanggil dipersidangan". ${ }^{48}$ Perlindungan hukum represif bertujuan untuk menyelesaikan sengketa. Dalam hal sengketa jual beli tanah ini dapat dilakukan gugatan perdata ke pengadilan negeri, hal ini sekaligus untuk menghindari "eighnt reichting” (main hakim sendiri).

\section{Sengketa Pertanahan Dalam Perjanjian Jual Beli Tanah}

Konflik menurut pengertian hukum adalah perbedaan pendapat, perselisihan paham, sengketa antara dua pihak tentang hak dan kewajiban pada saat dan keaadaan yang sama. Secara umum konflik atau perselisihan paham, sengketa diartikan dengan pendapat yang berlainan antar dua pihak mengenai ma-salah tertentu pada saat atau keadaan yang sama. Selanjutnya kata "Konflik" menurut kamus ilmiah popular adalah pertentangan, pertikaian, persengketaan, dan perselisihan. ${ }^{49}$

Sengketa pertanahan adalah perselisihan pertanahan antara orang perseorangan, badan hukum atau lembaga yang tidak berdampak luas secara sosiopolitis. Penekanan yang tidak berdampak luas inilah yang membedakan defenisi sengketa pertanahan dengan definisi konflik pertanahan. Sengketa tanah dapat berupa sengketa administratif, sengketa perdata, sengketa pidana terkait dengan

48 Maria Theresia Geme, Op.cit, hlm. 120

49 P. Parlindungan, 1994, Pendaftaran Tanah Indonesia (Berdasarkan P.P.24 Tahun 1997) Di/ engkapi Dengan Peraturan Jabatan Pejabat Pembuat Akta Tanah (P.P. 37 Tahun 1998), Bandung, CV. Mandar Maju. hlm. 159 pemilikan, transaksi, pendaftaran, penjaminan, pemanfaatan, penguasaan dan sengketa hak ulayat. ${ }^{50}$

Konflik pertanahan merupakan perselisihan pertanahan antara orang perseorangan, kelompok, golongan, organisasi, badan hukum atau lembaga yang mempunyai kecenderungan atau sudah berdampak luas secara sosiopolitis. ${ }^{51}$ Perkara pertanahan adalah perselisihan pertanahan yang penyelesaiannya dilaksanakan oleh lembaga peradilan atau putusan lembaga peradilan yang masih dimintakan penanganan perselisihannya di BPNRI. ${ }^{52}$

Beberapa faktor hukum yang menjadi akar dari konflik pertanahan belakangan ini antara lain: ${ }^{53}$

a. Tumpang Tindih Peraturan.

Undang-Undang Pokok Agraria sebagai induk dari peraturan di bidang sumber daya agraria lainnya, dalam perjalanannya dibuat beberapa Peraturan PerundangUndangan yang berkaitan dengan sumber daya agraria tetapi tidak menempatkan Undang-Undang Pokok Agraria sebagai undang-undang induknya, bahkan justru menempatkan Undang-Undang Pokok Agraria sejajar dengan undang-undang agraria. Undang-Undang Pokok Agraria yang mulanya merupakan payung hukum bagi kebijakan pertanahan di Indonesia menjadi tidak berfungsi dan secara substansial bertentangan dengan diterbitkannya berbagai peraturan perundang-undangan sektoral seperti UU Kehutanan, UU Pokok Pertambangan,

\begin{tabular}{ll}
\hline 50 & Ibid \\
51 & Ibid \\
52 & Ibid, hlm. 160 \\
53 & Ibid, hlm. 161-162
\end{tabular}


UU Transmigrasi dan lain-lain.

b. Tumpang Tindih Peradilan.

Pada saat ini terdapat tiga lembaga peradilan yang dapat menangani suatu konflik pertanahan yaitu Peradilan Perdata, Peradilan Pidana dan Peradilan Tata Usaha Negara. Dalam bentuk konflik tertentu, salah satu pihak yang menang secara perdata belum tentu menang secara pidana (dalam hal konflik disertai tindak pidana).

Beberapa Faktor Non Hukum antara lain: ${ }^{54}$

a. Tumpang tindih penggunaan tanah. Sejalan dengan waktu, pertumbuhan penduduk yang cepat mengakibatkan jumlah penduduk bertambah, sedangkan produksi pangan tetap atau mungkin berkurang karena banyak tanah pertanian yang beralih fungsi. Tidak dapat dihindarkan bahwa dalam sebidang tanah yang sama dapat timbul kepentingan yang berbeda. ${ }^{55}$

b. Nilai ekonomis tanah tinggi.

c. Kesadaran masyarakat meningkat adanya perkembangan global serta peningkatan perkembangan ilmu pengetahuan dan teknologi berpengaruh pada peningkatan kesadaran masyarakat. Pola pikir masyarakat terhadap masyarakatpun ikut berubah. Terkait tanah sebagai aset pembangunan, maka muncul perubahan pola pikir masyarakat terhadap penguasaan tanah, yaitu tidak lagi menempatkan tanah sebagai sumber produksi akan tetapi menjadikan tanah sebagai sarana untuk investasi atau komoditas ekonomi.

d. Tanah tetap, penduduk bertambah. Pertumbuhan penduduk yang sangat cepat

54 Ibid

55 Ibid baik melalui kelahiran maupun migrasi serta urbanisasi, serta jumlah lahan yang tetap, menjadikan tanah sebagai komoditas ekonomi yang nilainya sangat tinggi, sehingga setiap jengkal tanah dipertahankan sekuatnya.

Tipologi kasus pertanahan merupakan jenis sengketa, konflik dan atau perkara pertanahan yang disampaikan atau diadukan dan ditangani oleh Badan Pertanahan Nasional, secara garis besar dikelompokkan menjadi: ${ }^{56}$

1. Penguasaan tanah tanpa hak, yaitu perbedaan persepsi, nilai atau pendapatan, kepentingan mengenai status penguasaan di atas tanah tertentu yang tidak atau belum dilekati hak (tanah Negara), maupun yang telah dilekati hak oleh pihak tertentu.

2. Sengketa batas, yaitu perbedaan pendapat, nilai kepentingan mengenai letak, batas dan luas bidang tanah yang diakui satu pihak yang telah ditetapkan oleh Badan Pertanahan Nasional Republik Indonesia maupun yang masih dalam proses penetapan batas.

3. Sengketa waris, yaitu perbedaan persepsi, nilai atau pendapat, kepentingan mengenai status penguasaan di atas tanah tertentu yang berasal dari warisan.

4. Jual berkali-kali, yaitu perbedaan persepsi, nilai atau pendapat, kepentingan mengenai status penguasaan di atas tanah tertentu yang diperoleh dari jual beli kepada lebih dari 1 orang.

5. Sertipikat ganda, yaitu perbedaan persepsi, nilai atau pendapat, kepentingan mengenai suatu bidang tanah tertentu yang memiliki sertipikat hak atas tanah lebih dari satu.

56 Ibid, hlm. 164-166 
6. Sertipikat pengganti, yaitu perbedaan persepsi, nilai atau pendapat, kepentingan mengenai suatu bidang tanah tertentu yang telah diterbitkan sertipikat hak atas tanah pengganti.

7. Akta Jual Beli Palsu, yaitu perbedaan persepsi, nilai atau pendapat, kepentingan mengenai suatu bidang tanah tertentu karena adanya Akta Jual Beli palsu.

8. Kekeliruan penunjukan batas, yaitu perbedaan pendapat, nilai kepentingan mengenai letak, batas dan luas bidang tanah yang diakui satu pihak yang teiah ditetapkan oleh Badan Pertanahan Nasional Republik Indonesia berdasarkan penunjukan batas yang salah.

9. Tumpang tindih, yaitu perbedaan pendapat, nilai kepentingan mengenai letak, batas dan luas bidang tanah yang diakui satu pihak tertentu karena terdapatnya tumpang tindih batas kepemilikan tanahnya.

10. Putusan Pengadilan, yaitu perbedaan persepsi, nilai atau pendapat, kepentingan mengenai putusan badan peradilan yang berkaitan dengan subyek atau obyek hak atas tanah atau mengenai prosedur penerbitan hak atas tanah tertentu.

\section{E. Studi Kasus Dan Pertimbangan Hakim Dalam Menilai Ada Tidaknya ltikad Baik Dalam Perjanjian Jual Beli Tanah.}

Putusan hakim harus didasarkan pada hasil musyawarah majelis. Hal ini merupakan keniscayaan dalam proses pengambilan keputusan oleh hakim. Segala pendapat atau argumentasi hukum dikemukakan oleh masingmasing hakim anggota majelis sebagaimana diatur dalam Pasal 14 Undang-undang Nomor 48 Tahun 2009 tentang Kekuasan Kehakiman, yang menyatakan: "Putusan diambil berdasarkan sidang permusyawaratan hakim yang bersifat rahasia".

Musyawarah majelis merupakan perundingan yang dilakukan oleh hakim untuk mengambil kesimpulan terhadap sengketa yang sedang diadili untuk selanjutnya dituangkan dalam putusan. Dalam musyawarah majelis ini, hakim diperbolehkan untuk mengajukan pendapat berbeda (dissenting opinion) sepanjang didasari pada argumentasi yang kuat dan rasional. ${ }^{57}$ Putusan hakim harus dilandasi atas pertimbangan hukum (legal reasoning, ratio decidendi) yang komprehensif. Putusan hakim yang tidak cukup pertimbangannya menyebabkan putusan tersebut dapat dikatagorikan onvoldoende gemotiveerd. Keadaan demikian merupakan permasalahan yuridis, karenanya dapat dibatalkan oleh pengadilan yang lebih tinggi.

Pasal 50 Undang-Undang Nomor 48 Tahun 2009 tentang Kekuasaan Kehakiman menyatakan: "Putusan pengadilan selain harus alasan dan dasar putusan, juga memuat pasal tertentu dari peraturan perundangundangan yang bersangkutan atau sumber hukum tak tertulis yang dijadikan dasar untuk mengadili" ${ }^{58}$ Kemudian dengan maksud yang sama, Pasal 178 ayat (1) HIR/189 ayat (1) R.Bg, menyatakan: "Hakim karena jabatannya waktu bermusyawarah wajib mencukupkan segala alasan hukum yang tidak dikemukakan oleh kedua belah pihak". Pasal tersebut secara tegas memerintahkan kepada hakim untuk memberikan pertimbangan yang cukup dan lengkap dalam setiap putusannya. Cukup dan lengkap di sini ditafsirkan sebagai keadaan dimana hakim tersebut telah mem-

\footnotetext{
57 M. Natsir Asnawi, 2014, Hermeneuitika Putusan Hakim, Yogyakarta, UII Press, hlm. 43

58 Ibid, hlm. 44
} 
pertimbangkan seluruh alat-alat bukti yang diajukan para pihak, fakta-fakat hukum yang terungkap, serta seluruh bagian dari dalil gugatan Penggugat. ${ }^{59}$

Dari berbagai putusan terlihat bahwa pengadilan belum memiliki pemahaman yang mendalam dan konsisten tentang makna itikad baik yang dimaksud Pasal 1338 ayat (3) KUHPerdata. Kemudian berkaitan dengan sikap pengadilan tentang itikad baik ini terlihat bahwa pada mulanya pengadilan lebih mengedepankan asas facta sunt servanda dan mengesampingkan itikad baik. Belakangan, itikad baik lebih dikedepankan Bahkan, dengan itikad baik, penerapan facta sunt servanda dikesampingkan.

Dewasa ini dalam berbagai sistem hukum, itikad baik dalam pelaksanaan kontrak adalah mengacu kepada isi perjanjian yang harus rasional dan atau patut. Itikad baik dalam konteks Pasal 1338 ayat (3) KUHPerdata harus didasarkan pada kerasionalan dan kepatutan.

Standar yang dipakai dalam me-nilai itikad baik dalam pelaksanaan kontrak adalah standar objektif. Dengan ini maka perilaku para pihak dalam melaksanakan kontrak dan penilaian terhadap isi kontrak harus didasarkan pada prinsip kerasionalan dan kepatutan. Pengadilan belum memiliki pemahaman yang mendalam dan konsisten tentang makna itikad baik yang dimaksud Pasal 1338 ayat (3) KUHPerdata. Pada mulanya pengadilan lebih mengekedapankan facta sunt servanda dan mengesampingkan itikad baik. Apabila suatu bidang tanah sudah diterbitkan sertipikatnya secara sah atas nama orang atau bidang hukum yang memperoleh tanah tersebut dengan itikad baik dan secara nyata menguasai tanah tersebut, maka pihak lain yang merasa mempunyai hak atas tanah tersebut tidak dapat lagi menuntut haknya, apabila dalam jangka waktu 5 (lima) tahun sejak diterbitkannya sertipikat tersebut, tidak mengajukan keberatan secara tertulis kepada pemegang sertipikat dan Kepada Kantor Pertanahan atau tidak mengajukan gugatan ke pengadilan mengenai penguasaan tanah atau penerbitan sertipikat. Inilah yang disebut rechtsverwerking. Ketentuan ini merupakan penyempumaan dan penegasan terhadap sistem publikasi negatif bertendensi positif dari pendaftaran tanah yang diamanatkan Undang-Undang Pokok Agraria (UUPA). Selama ini orang yang tercantum namanya dalam sertipikat selalu dihadapkan pada kemungkinan adanya gugatan dari pihak lain yang merasa mempunyai hak atas bidang tanahnya. Tetapi dengan penentuan batas waktu ini, maka orang yang tercantum namanya dalam sertipikat akan bebas dari kemungkinan adanya gugatan setelah lewat waktu 5 (lima) tahun dan statusnya sebagai pemilik tanah akan terus dilindungi sepanjang tanah itu diperoleh dengan itikad baik dan dikuasai secara nyata oleh pemegang hak bersangkutan atau kuasanya. ${ }^{60}$

Hakim tidak lagi hanya sekedar membaca dan menerapkan undang undang, tetapi juga melakukan proses kreatif yang luar biasa untuk menangkap sekalian fenomena dan aspirasi keadilan yang ada di masyarakat. Hakim mulai menempatkan dirinya sebagai garda utama dalam mewujudkan keadilan di masyarakat. Tidak hanya sampai di situ, hakim pun mulai menegaskan eksistensinya sebagai pembuat hukum (judge made law) yang lebih progresif dan responsif dengan gerak air perubahan dinamika sosial dan hukum di masyarakat. 
Hakim telah memberikan jiwa yang sangat kuat dalam putusan-putusannya, sehingga apa-tisme dan pesimisme masyarakat selama ini terhadap putusan hakim perlahan dapat berkurang, dan pada saat yang sama berubah menjadi kepercayaan dan optimisme tinggi akan terwujudnya keadilan sosial bagi seluruh rakyat Indonesia. ${ }^{61}$

Selain itu, faktor keberanian untuk keluar dari pakem yang ada serta keinginan kuat untuk mewujudkan keadilan dan kemanfaatan pada setiap putusan, pada akhirnya akan menciptakan perbedaan gaya atau tipologi bagi masing-masing hakim. Memang, dan harus diakui, kenyataan saat ini menunjukkan masih banyak hakim yang memutus dengan optik yang sangat positivistik, sementara lainnya sudah menggunakan pendekatan yang multidisc-ipliner.

Bila dianalisis lebih jauh, perbedaanperbedaan pendekatan yang dilakukan hakim dalam memutus suatu perkara dapat dikategorikan ke dalam dua kelompok, yaitu perbedaan dari segi paradigma perbedaan dari segi nilai-nilai yang dianut. Dari sisi paradigma, dapat diketahui bahwa hakim terbelah menjadi dua, yaitu paradigma positivistik dan paradigma di luar positivistik. Hakim akan terbagi pada dua pendirian, yaitu pendirian hakim yang memposisikan dirinya sebagai corong undang-undang sehingga mengabdi sepenuhnya pada teks undang-undang dan pendirian hakim yang memposisikan dirinya sebagai kreator bagi terciptanya keadilan substantif. ${ }^{62}$

Dengan nilai-nilai dan kayakinan yang dianut oleh hakim, ada sementara hakim yang memegang teguh idealisme hukum

61 Ibid

62 Ibid, hlm.182 dengan berupaya memutus setiap perkara yang ditanganinya dengan seadil-adilnya, sementara itu, sisi lain ada hakim yang memutus dengan melihat sisi manfaat dari putusan apa yang akan diambilnya. Putusannya dipertimbangkan sedemikian agar konkuisi yang diambil benarbenar dapat memberi manfaat nyata bagi para pihak dan juga masyarakat. Namun, tidak sedikit pula hakim yang memutus dengan menggabungkan nilai-nilai tersebut, sehingga menjadi putusan yang lebih komprehensif. ${ }^{63}$

\section{PENUTUP}

1. Perlindungan hukum bagi pembeli yang beritikad baik dalam pelaksanaan perjanjian dalam hal ini jual beli tanah yaitu sejak praperjanjian dan sesudah perjanjian harus dilindungi sebagaimana ditentukan Pasal 1341 KUHPerdata, Pasal 1491 dan Pasal 1492 KUHPerdata, dan isi perjanjian jual beli tanah juga harus rasional atau patut dilaksanakan dengan itikad baik sebagaimana dalam konteks Pasal 1338 ayat (3) KUHPerdata.

2. Hakim dalam pertimbangan hukumnya belum memiliki pemahaman yang mendalam dan konsisten tentang makna itikad baik yang dimaksud dalam Pasal 1338 ayat (3) KUHPerdata. Standar yang digunakan hakim dalam menilai adanya itikad baik dalam suatu perkara sengketa tanah atau pelaksanaan jual beli tanah adalah standar objektif, yaitu standar yang mengacu kepada perilaku para pihak dalam melaksanakan perjanjian dan penilaian terhadap isi perjanjian jual beli tanah harus didasarkan pada kerasionalan dan kepatutan. 


\section{BIBLIOGRAFI}

\section{Literatur/Buku-Buku}

Badrulzaman, Mariam, Darus, Kitab UndangUndang Hukum Perdata Buku III, Tentang Perikatan Dengan Penjelasan, Bandung Alumni.

-------, 2001, Kompilasi Hukum Peri-katan, Bandung, PT. Citra Aditya Bakti. Bahri, Syamsul, 1981, Hukum Agraria Indonesia Dulu dan Kini, Padang, Fakultas Hukum dan Pengetahuan Masyarakat, Universitas Andalas.

Faiz, Muhammad. Kemungkinan diaj-ukan Perkara dengan Klausula Arbitrase ke Muka Pengadilan, tanggal 12 September 2006.

Gautama, Sudargo, 1994, Himpunan Yurisprudensi Indonesia yang Penting untuk Praktek Sehari-hari (Landmark Decissions), Berikut Komentar, Jilid 9, Bandung, Citra Aditya Bakti.

Gunawan Widjaja dan Kartini Muljadi, 2003, Jual Beli, Jakarta, PT RajaGrafindo Persada.

Harsono, Boedi, 1971, Undang-Undang Pokok Agraria, Sejarah Penyusunan, Isi dan Pelaksanaannya, Bagian Pertama, Jilid Pertama, Jakarta, Djambatan. 2007, Мепијu Penyempurnaan Hukum Tanah Nasional, Jakarta, Universitas Trisakti, ed.3.

Hadjon M Philipus, 1987, Perlindungan Hukum Bagi Rakyat Indonesia, Surabaya, PT. Bina IImu.

HS, Salim, 2003. Hukum Kontrak Teorie Teknik Penyusunan Kontrak, Jakarta, Sinar Grafika.

Hulman 2013, Kumpulan Kaidah Hukum Putusan Mahkamah Agung Panjaitan,
Republik Indonesia Tahun 1953-2008, Berdasarkan Penggolongan, Jakarta, Prenadamedia Group.

J.Satrio, 1995, Hukum Perikatan yang Lahir dart Perjanjian, Bandung, PT Citra Aditya Bakti.

Marzuki, Mahmud, Peter, 2005, Penelitian Hukum, Jakarta, Prenada Media. Martin Joseph Schermaier, "Bona Fides in Roman Contract Law”, Rei-nhard Zimmerman dan Simon Whittaker, eds

Miru, Ahmadi, 2007, Hukum Kontrak Perancangan Kontrak, Jakarta, PT Raja Grafindo Persada.

M. Natsir Asnawi, 2014, Hermeneuitika Putusan Hakim, Yogyakarta; UII Press.

\section{Peraturan Perundangan-Perundangan}

Undang-Undang Nomor 5 Tahun 1960 tentang Peraturan Dasar Pokok-Pokok Agraria (Lembaran Negara Republik Indonesia Tahun 1960 Nomor 104, Tambahan Lembaran Negara Republik Indonesia Nomor 2043)

Undang-Undang Nomor 2 Tahun 1986 jo Undang-Undang Nomor 8 Tahun 2004 jo Undang-Undang Nomor 49 Tahun 2009, tentang Peradilan Umum (Lembaran Negara Republik Indonesia Tahun 2004 Nomor 34)

Undang-Undang Nomor 48 Tahun 20-09 tentang Kekuasaan Kehakiman (Lembaran Negara Republik Indonesia Tahun 2009 Nomor 157 Tambahan Lembaran Negara Republik Indonesia Nomor 5076)

Undang-Undang Nomor 8 Tahun 1999 tentang Perlindungan Konsumen (Lembaran Negara Repub1ik Indonesia Tahun 1999 Tambahan Lembaran Negara Republik Indonesia Nomor 3821) 
Peraturan Pemerintah No.24 Tahun 1997, tentang Pendaftaran Tanah (Lembaran Negara Republik Indonesia Tahun 1997 Nomor 59 Tambahan Lembaran Negara Republik Indonesia Nomor 3696)

\section{Kamus/Internet:}

Khoirul, Hukum Kontrak. Slide 1.Ppt Http//: Sunan-ampel.ac.id

Nur, Muliadi, Asas Kebebasan Berkontrak dalam Kaitannya dengan Peljanjian Baku (Stand-ard Contract).www.pojokhu-kum. com.

Raimond Flora Lamandasa, Penegakkan Hukum (online), http//r-aimondfloralmandasa. blogpost.com/2008/05/penegakkanhukum oleh-raimond-flora.h-tml, diakses tanggal 25 Okt-ober 2015.

Salman, http :1/prasxo. wordpress. com/2011/021171/detinisi-perlindungan- hukum/, diakses pada tanggal 8 Desember 2015. 